\title{
Extended homozygous haplotypes at genes involved in brain development associated with autism
}

Ping-l Lin

From Beyond the Genome 2012

Boston, MA, USA. 27-29 September 2012

\section{Background}

Recent evidence has suggested that extended homozygous haplotypes (EHH) in several genomic regions may be associated with risk of psychiatric disorders (for example, schizophrenia). The phenomenon of EHHs may arise from recent positive selection, inbreeding, as well as recessive models.

\section{Materials and methods}

We used Affymetrix 500K SNP arrays to search for EHH in 1,385 affected individuals and 1,498 unaffected individuals. The EHH was defined as at least 100 contiguous homozygous SNPs. To interrogate the associations between EHHs and autism, logistic regression analysis with generalized equation estimation model to adjust for intrafamily correlation was performed. We also examined if any of the associated EHHs were related to deletions by examining the data of copy number variants. Finally, we checked if any associated EHHs contained genes with signatures of recent positive selection in the Hapmap sample. We used the Sidak method to correct for multiple tests.

\section{Results}

The best finding was obtained at the HMLGCL1 gene $\left(P=3 \times 10^{-5}\right.$, odds ratio 0.15$)$. The HMLGCL1 gene has been found to be highly expressed in some brain regions. Other genes harbored in regions enriched with EHHs associated with autism include ZFP91, CNTF, NAPL1 and TLE4. We also used the webtool Panther to assess if this set of genes is over-represented in any pathways. The results suggest that these genes collectively may be involved in the Wnt signaling pathway

Division of Biostatistics and Epidemiology, Department of Pediatrics, Cincinnati Children's Hospital Medical Center, Cincinnati, OH 45229, USA and neurodevelopment process. No remarkable evidence for recent positive selection was obtained for most of these loci, except the TLE4 gene $(P=0.008)$.

\section{Conclusions}

Taken together, these genes involved in brain development may harbor variants that exert a recessive effect on the risk of autism. Further work is warranted to replicate these findings in other populations.

Published: 1 October 2012

doi:10.1186/1753-6561-6-S6-P24

Cite this article as: Lin: Extended homozygous haplotypes at genes involved in brain development associated with autism. BMC Proceedings 2012 6(Suppl 6):P24.
Submit your next manuscript to BioMed Central and take full advantage of:

- Convenient online submission

- Thorough peer review

- No space constraints or color figure charges

- Immediate publication on acceptance

- Inclusion in PubMed, CAS, Scopus and Google Scholar

- Research which is freely available for redistribution

Submit your manuscript at www.biomedcentral.com/submit
() Biomed Central

\section{() Biomed Central}

